enough complain of heaclache and stomach-ache. 'This is" followed by sudden repeated vomiting. The tongue is coated, the breath offensive and the bowels generally constipated, although there may be a relaxed condition of the intestine. There is a slight temperature of $101^{\circ}$ or $102^{\circ} \mathrm{F}$.

Fred 1)., two and one-half years of age. Iad always been healthy and strong until he was one and one-half years old. At this time the parents became less enreful as to his feeding. He has been more or less constipated since birth. About three months ago he was given some grape-fruit just before his milk feeding. This was followed by an acute upsed, and, aceording to his mother, his stomach would retain nothing for five lays. Ile is a very nervous child, always has dark rings under his eyes, and slecps poorly, awaking at the slightest sound and lying awake half of the night. II has nocturnal enuresis. Since his last attack, his breath has been foul. 'There has been a slight loss of weight, and lately he has been passing some mucous in his stools.

The morning of the day I saw him, he was given some peppermint ereams by his father and then went for a long sleigh ride, the morning being very cold. On his way home he began to vomit copiously and became quite prostrated.

I found him very drowsy and very nauseated. 'The skin was cool, and the pulse rapid and weak. The temperature was $97.2^{\circ} \mathrm{F}$., but within an hour it arose? to 100. 1. The stool obtained by enema was well digested but foul and contained considerable mucous. The urine was very acid, the indican and urophain greatly increased. After the next forty-eight hours the vomiting ceased and the indican disappeared, the child having. been put on buttermilk.

\section{INTESTINAL TOXEMIA.}

While components of dead bacteria furnish a certain amount of poisonous proteins, and living hacteria in the intestine excrete ferments or toxins, substances produced by bacteria from the culture media are possibly the most important source of intestinal intoxication, the virulence of the ptomaines formed depending not only upon the micro-organisms, but upon the character of the food material in which it is growing.

The products formed during the process of putrefaction are indol, skatol, phenol, cresol, leucin, tyrosin, ammonia and hydrogen sulphide; also volatile fatty acids, oxalic acid, uric acid and the xanthin bodies. The most important of these bodies is indol, varying amounts of which we find in the urine in the form of indican, whose etiological relationship to nervous symptoms has been clemonstrated, although the alssence of indican does not rule out intestinal intoxication, since severe forms have occurred in which indol was not an etiological factor.

Rachford ${ }^{5}$ thinks that these severe albuminous fermentations are more common in a child than in the adult. He bases his view on the fact that the Icl. formation of the stomach is not so well developed in the young child, and, therefore, not as (apable of exercising the same control in preventing intestinal fermentation; also that the filtering function of the liver is not as well carried out as in the adult.

As an example of the severe nervous symptoms due to the absorption from the intestinal canal, I would like to quote the following case.

This oceurred in a five-ycar-old Italian child who lived in a very ignorant family under very filthy eonditions. 'The father, who was a market peddler, lost a child two years ago from meningitis. From what information I could obtain, the ehild was in the habit of eating some of the left-over slightly spoiled fruit. When I first saw him, so profound was the intoxication that it strongly suggested meningitis. He was semi-conseious, being aroused with difficulty. 'The temperature? was $105^{\circ} \mathrm{J}$., the respiration increased, as was the pulse, which was full and bounding. Nothing was found in the lungs. His face was flushed, pupils irregular, and responding slowly to light. There was sight rigiclity to neck, increased patellar reflexes, marked Kernig's. There was no Babinski or ankle clomus. At times there were quick strong contractions of the muscles of the lower extremities. IRectal examination showed the lower bowel packed full of feces. Jumbar punctiure was offered, but the father refused to let it be performed.

This child had been ill three days, the onset being ushered in hy vomiting, headache, slight fever and some abdominal pain. 'The bowels had moved slightly every day. The first day his physician gave him a good cleaning out, with the result of a drop in the temperature and an improvement in all of the symptoms. As soon as the bowels became costive, the temperature went up) again, so that at the time I saw him his temperature was 105. 'The movements now obtained from day to day were very foul, and contained a good deal of mucous. With a continued cleaning out, the nervous symptoms disappeared and he made a good recovery.

In conclusion, while the parent's tale of a "bilious attack" may mean the most innocent of digestive upsets, their diagnosis must be carefully sifted and a thorough physical and clinical examination made and the other possibilities excluded.

JH:RKRENCRH.

1 Common Disorders and I Diseatues of Childhood, p. 231.

3 Moynihan: Appendix Dyнpepsia, Brit, Med. Jour., Jan. 29, 1910. 3 Rachford: Neurotic Disorders of (Childheod, 1905, p. 222.

- Comby: Arch. de Mod. des Iinf., vol. xii, p. 726.

S Rachford: Neurotio Disorders of Childhood, 19(0), p. 51

\section{THE ETIOLOGY OF COMMMON COLDS.}

Ву А. COOLADOL, JR., M.l., BOHION,

Assistant Professor of Larymoolony, Harvard Mfedical School: Physician for Diseases of the Throat, Massachusetts General Hospilal.

IN an editorial in the Journal of May $26^{1}$ on the "Prevention of Cornmon Colds," it is assumed that this term means an acute bacterial infection of the mucous memlorane of the upper respiratory tract. With this assumption I am in sympathy, more perhaps because I think that in case of dispute it is the proper sicle to take, than because it is absolutely accurate. The term " cold" is a popular rather than a scientific term, and as such means different things to different men. As expressing a pathological condition it has long been abandoned by the medical profession. Its use is still forced upon the family practitioner by his patients, but as the word is no longer orthodox, he can twist its meaning to suit the oceasion.

To many the word "cold," at least as far as it 1 Vol. olxii, p. 718. 
applies to the nose, is associated with a group of mucous membranc, especially in the latter. The symptoms commonly called coryza. For instance, vocal cords may or may not eseape. But none we have what is known as " rose eold," which is of these local appearances are really characteristic:; not a hacterial infection. The question is then the diagnosis must largely be made from the? one of a hefiter definition of an ancient but still active worel, which eamnot he climinated from the intereourse botwern physician and patient, even if it were desirable to do so.

A similar uncertainty of lofinition hangs over such words as "rhinitis" and "pharyngitis," which are often used to include not only true inflammation, but any disturbance of function or secretion or sensation which eannot, be classified under some more definite pathological heading. With advance of knowledge a constantly increasing proportion of eases are found to be dependent upon some local lesion or definite infection or general condition which makes their classification and description more exact; there still remain, however, a large number of eases in which the etiology is obseure and the local appearaness misloading. Among the acute disorder's of the nasal chambers we may distinguish some as due to infortion and others as arising from a local irritability and vasomotor disturbance. A type of the first class would he a rhinitis whore the infecting organism is known, and of the second the eoryza inclued in some persons hy the pollen of ecertain plants or hy sitting in a draft. In some (ases both of these ritological factors may exist, and in many more it, may be uncertain or a question of individual opinion whether an infection or some form of local or systemic irritation is the eause of the symptoms.

The more definite processes, such as diphtheria on the one hand and hay fever on the other, are no longer classified as simple acule rhinitis or "rold in the head." Among those that remain it. is important to distinguish as far as possiblo whether wo are dealing with an infection or with some systemic or local irritation.

Amomg the varieties of acute rhinitis or cold, there is one form which it secms to me is so (eommon and constant in its symptoms that it should be elasised as a distinet and definite disease. Briefly, the symptoms are as follows: The first, suspicion on the part of the patient that he has such a cold starts from an irritation or sensation in some spot, often the nasopharynx, occasionally the larynx, nose or tonsil. During the next fow hours this irritation extends to noighboring regions, and this continues perhaps for a fow days, lut the amount of its extension varies in clifferent arses. It may involve the nose, the sinuses, the pharynx, the larynx, the trachea and the bronchi, rarely the stiomach, but it may spare any of these parts. The loc:al appearances are in most cases less marked than the severity of the symptoms would suggest. There is an increase in redness of the mucous membrane involved, and other signs of inflammation, generally of a mild type. In the nose the turbinates become engorged during the symptoms of coryza, and abundant watery secretion is secn. In the pharynx the mucous membrane becomes red, especially about the so-called follicles and the faucial pillars. In the larynx and the trachea there is a distinct reddening of the patient's symptoms and history.

This eommon form of cold runs a more or lesis definite course. It is generally possible to trace its extension from one region of mucous membrane to another. Although the symptoms eonnected with it are dependent upon the region involved and the severity of the attack, these symptoms do not, suddenly arise and suddenly disappear, as is often the case with vaso-motor rhinitis. It appears to spread between persons in close contact, with each other, and with an incubation period of from two to four days. It ocecurs less frequently in summer than at other times of the year, and is rather nore common in children than in adults, although persons vary in the frepuency and severity of the attacks. 'The' process is essentially an acute one, the period of cxtension scldom lasting many days, and all symptoms and appearane('s sometimes disap)pearing in a fow hours or days. During this period there is seldom any rise in temperature, no formation of pus nor increase in the number of bacteria to be found. In some regions, however, notably the nasal and aceessory eavities and the bronehi, there may be a purulent invasion following the acute stage, suggesting the result of local failure of resistance, due perhaps to a disturbance of function of the self-cleansing ciliated mucous membrane. 'This second or subaceute stage is characterized by the formation of mueopurulent seceretion containing different micro-organisms, it, varies much in severity and length, and may' lead the way to serious trouble. I)uring the: primary stage there is a varying amount of loc:al and general diseomfort, depending upon the extent, of the trouble and the idiosynerasies of the patient. When a purulent stage follows, the temperature and the severity of the discase depend upon the locality and extent of the secomelary complications and the invading organsim.

No specific micero-organism has been found to explain the cause of this most common form of acute cold, but this is equally true of other diseases whose nature is evidently contagious. $\Lambda$ s the community and even a majority of the medical profession insist on secking some recent exposure to weather as the eause of cach case as it, arises, the sometimes obvious contagion is overlooked. The common belief is that the start is given to the process by some chilling of the skin, as a result of imprudence in exposure, or in dress, acting in some way through ehanges in the body temperature or through the nervous system; or that exposure frequently gives a chance to some pathogenic organism which is waiting for the opportunity. While this latter is perhaps sometimes true in such cases as an already existing bronchitis, I believe that a typical cold never starts in this way.

There is much evidence tending to show that. these colds are often directly contagious. If wo can prove that a definite pathological process is 
often due to contagion, the same process is probably always due to contagion.

It is a matere of common knowlerlge that epidemices of simple colds may oreour. Hven more common is the observation that, when they appoar in a large family of ehildren they go through the family or even a sechool. Families of children often remain in the country all summor entirely free, but soon after beginning sehool start a series of colds which spread to other mombers of the houschold. If, however, a cold should start in the miclulle of summer it may, in the same way, go through a family or several families. These cases do not begin all at once, as would be expected if they were due to the weather, but in secpuence.

Evidence may be eited also that where no chaner for contagion exists this usual form of cold does not arise from exposure. Nansen mentions that, on his Polar expedition no one ever had a cold. In the more recent experlition to the Antaretic under shackloton, Dr. Marshall reports that the only suggestion of colds in the head which oceurred was on oponing a bunclle of blankets, when symptoms of acute rhinitis appoared in the hut, but soon subsided after excreise in the open air, - obviously a vasomotor and not an infectious rhinitis. I have notes of reports of other long voyages where, in spite of exposure, physical weakness and unhealthy surroundings, acute colds did not appear until after the vesisel reached port. I have been told by the captain of a whaler that the people in Creenland never have colds except when it is hrought by a ship.

My own experience tonds to agree with those who have observed that colds have an incubation poriorl of from two to four days, that they remain contagious for several clays and that the acepuired immunity is short. Also that the discase is carried esperially hy snoreging, coughing, cmbracing and speaking at close range, possibly by towols and other utensils, but only for a short time, and that mueh can be clone to prevent its spreal hy acting along these lines. It sprearls more frecuently among children because they are in more frecuent contact with each other than are adults. 'To prevent colsls a little care given to avoiding close contact will accomplish much more than a great deal given to details of clothing and exposure to weather.

The suseeptibility of different persons varies greatly. 'There: would appear to be sometimes cither a lack of general resistance to the infection or a local susceptible arca. Perhaps the larger amount of lymphoid tissue in the pharynx of rhildren increases their susceptilility. I have not been able to prove that there is any relation between a person's susceptilility to colds in the hearl and his general health and strength.

In atdition to the above-described form of cold, there are other types which, although having some symptoms in common, differ enough to make it probable that, although infectious, they are due to some other organism. These generally run a more prolonged course. They may be accompanied from the start by a purulent secretion and sometimes by rise of temperature. They are, as a rule, less contagious than the more common form. Hpiclemies in which aceute rhinitis is a prominent symptom are various and not, uncommon. It aceompanies moasles and other constitutional discasce. It may or may not, apperar in infection by the haveillus of influen\%a. 'The micrococeus catarrhalis apparently somotimes (:auses an epidemice of rhinitis. and pharyngitis. In other cases of acute or subacoute inflammation the

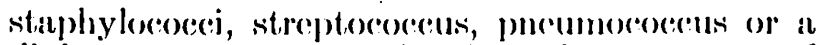
diplococeus are probably the primary cause of the disturbance, certainly they are there in large: numbers. Some of these organisms are common in healthy throats, and conseguontly acoute attacks caused by them would have to be explained by a lowered resistance and would not appear as an epirlemice. But in the more common form of cold the theoretical micro-organism which starts the process and carries the contagion has not yot been proved, and is probably nome of these. If we may classify it as contagious we may assume the micro-organism.

The eriticism that the persomal experience of many, and the common belice of eenturies, proves that a common cold is gemerally the result of exposure may be answered in different ways. Within a comparatively short timo the acecpted etiology of several discases has berol radically changed, and gencrally in the direction of assigning a dofinite ceause to a dofinite discase. In one: sense a "cold" is not a dofinite disease inasmuch as the term may be used to inclucle various: symp)toms of vasomotor origin. J3ut this is not the kind that is commonly meant when the worel "cold" is used. Symptoms of vasomotor origin come on at the time of rxposure, and their duration is dependent upon extermal comelitions. 'They do not run a definite course extending from onc region of mueous membrane to anothere, and they seldom load to purulent sereomdary complieations. When we recegnize more definitely the eommon type of infections cold, and the differences between it and coryza due to vasomotor disturbanece, wo may classify the latter with hay fover and its kindred, and announce that a "real cold" is a contagious disease. I think that the community would gain much by this assumption. 'The ol)jec:tion to drafts and wet and cold in modration which incluees humanity to shut itsolf into airtight inclosures is often due to an unwarrantable fear of "catching" just those discascs which arc, in fact, communicated by sncering, (eoughing and poor ventilation.

Rad Cross Mine Wonk.-- The American National Red Cross plans to introduce in the bituminous mining districts the first aid to the injured system which has been in use for several years in Pennsylvania. 'The Pullman Car Company has donated a ear in which visits will be made to the mines throughout the country, and instruction will be given to employers and employess in the most approved first-aid methods. 'The railroads over which the car will travel have, with the sanction of the Interstate Commeres Commission, agreed to furnish free transportation, and it is expected that the work will be begun during the latter part of the month under the supervision of Dr. M. J. Shields, - Med. Record. 